\title{
KEBERAGAMAAN INKLUSIF ANAK USIA DINI DALAM MASYARAKAT MINORITAS: \\ Studi Toleransi dalam Keluarga Ahmadiyah Manislor, Kuningan, Jawa Barat
}

\author{
Atik Wartini \\ Kamulan School Yogyakarta \\ arimob16@gmail.com \\ Shulhan \\ UIN Sunan Kalijaga \\ shulhan.live@gmail.com
}

\section{ABSTRAK}

Penelitian ini merupakan riset lapangan. Tema yang diangkat dalam penelitian ini adalah keberagamaan inklusif anak usia dini di keluarga Ahmadiyah Manislor, Kuningan, Jawa Barat. Ada tiga hal yang menjadi fokus penelitian ini yaitu konsep keberagamaan inklusif, pendidikan anak usia dini dalam keluarga Ahmadiyah Manislor Kuningan Jawa Barat serta implementasi keberagamaan inklusif AUD pada masyarakat tersebut. Penelitian ini menggunakan pendekatan analisis isi untuk menjelaskan konsep keberagamaan inklusif anak usia dini dan pendekatan fenomenologi untuk memotret toleransi keberagamaan anak usia dini pada keluarga tersebut. Hasil penelitian ini yaitu: (1) Konsep keberagamaan inklusif anak usia dini dapat dibangun 
melalui pembentukan identitas anak. (2) Pendidikan anak usia dini keluarga Ahmadiyah Manislor dilakukan melalui pembiasaan, pengenalan konsep cintai semua dan tak ada satupun yang dibenci, dialog dan penanaman jiwa sosial. (3) Implementasi keberagamaan inklusif keluarga Ahmadiyah Manislor dilakukan dengan toleransi, pembentukan identitas dan pemenuhan kebutuhan anak.

Kata kunci: Pembentukan identitas anak, Toleransi, Ahmadiyah

\section{ABSTRACT}

This field research basically explore inclusive religiosity of early childhood among Abmadiyah families at Manislor Kuningan West Java. In this study, there are three research questions dealt with the concept of inclusive diversity for early childhood, the tolerance education within the Ahmadiyah families and the implementation of religious tolerance for early childhood in Ahmadiyah families at Manislor Kuningan West Java. This study uses content analysis approach to explain the concept of inclusive diversity of early childhood and phemenology approach to photographing religious tolerance within their family. The results of this research are: (1) The concept of inclusive diversity for early childhood based on self identity building. (2) Tolerance education for children within Abmadiya families at Manislor done through attitude, spirit "Love for All and Hatred for None, dialog and social life building. (3) The implementation of religious tolerance for early childhood in abmadiyya families at Manislor through tolerance, self identity building and meeting children basic needs.

Keywords: Self Identity Building,Tolerance, Ahmadiyah.

\section{A. Pendahuluan}

Keragaman masyarakat (pluralitas) menuntut adanya sikap toleransi untuk mencegah disharmonisasi hubungan. Toleransi, selalu menjadi isu yang sangat hangat baik dalam kontek sosial, 
budaya dan agama. Berbicara tentang toleransi, tidak akan ada gunanya jika masih sebatas pengetahuan saja. Bisa jadi yang terjadi hanyalah adanya sikap eksklusifitas antar berbagai kelompok. Oleh karena itu, perlu adanya suatu upaya agar kesadaran toleransi dapat terbangun pada setiap individu. Dewasa ini, masih terdapat sebagian masyarakat yang hanya mendengar isu ekslusifitas pada kelompok tertentu, dengan tidak mengkonfirmasi, bagaimana yang sesungguhnya. Kebiasaan ini akan menjadi suatu budaya yang buruk dan turun-temurun pada kelompok tertentu membentuk stereotipe terhadap kelompok tertentu.

Budaya tidak adanya dialog atau keterbukaan antar kelompok, berimplikasi terhadap perpecahan suatu bangsa. Cara pandang negatif terhadap pihak lain dapat terjadi melalui sosialisasi nilai dalam pola asuh anak di lingkungan keluarga. Pada gilirannya nilai ini akan tersosialisasi secara turun temurun. Keluarga mempunyai peran yang lebih penting dalam proses tumbuh dan berkembangnya anak. Seperti yang di katalakan oleh John Lock (1632-1704), tentang teori "tabularasa”, yaitu anak dilahirkan seperti tablet kosong atau kertas putih. Dimana lingkungan akan membentuk pola pikir anak serta pengalaman mempunyai posisi yang penting untuk menentukan perkembangan anak. Pengalaman-pengalaman penting yang disajikan untuk anak melalui pola asuh keluarga akan menentukan juga, bagaimana kesadaran toleransi terbangun baik dalam aspek sosial, budaya dan agama.

Belajar tentang kesadaran toleransi, dalam keberagaman inklusif salah satunya dapat dilakukan dengan cara hidup bersama dengan keluarga Jemaat Ahmadiyah Manislor, Kuningan Jawa Barat. Interaksi merupakan suatu upaya untuk dapat membangun kesadaran toleransi dan melihat secara mendalam konsep keberagamaan inklusif, khususnya toleransi pada anak usia dini (AUD) di keluarga Jemaat Ahmadiyah Manislor Jawa Barat. Hal demikian karena masa kanak-kanak merupakan masa golden age, dimana segala hal yang dilihatnya baik secara sadar atau tidak akan 
tersimpan dalam memori otaknya, yang ketika dewasa kelak akan digunakan sebagai bahan untuk berfikir. Begitu dahsyatnya, masa perkembangan ini sehingga penting kesadaran toleransi ditanamkan sejak dini, sehingga selanjutnya dapat terlahir generasi yang inklusif dalam keberagaman baik dalam aspek sosial, agama dan budaya.

Dewasa ini masih terdapat sikap eksklusif pada sebagian kelompok/ masyarakat yang dalam memandang perbedaan atau pluralitas tidak hanya merugikan orang lain. Tetapi sesungguhnya juga merugikan diri sendiri, karena sikap eksklusifitas, tidak jarang membuat tekanan batin atau sakit hati yang mendalam sehingga terdapat problem batin yang membuat hidup tidak nyaman karena tidak bisanya menghargai dan menerima perbedaan pemahaman agama yang beragam. Oleh karena itu, perlu adanya upaya untuk membangun sikap inklusif pada keberagamaan, sehingga setiap orang atau anak mempunyai kesadaran toleransi yang menghargai perbedaan keberagamaan sehingga dapat membawa kemaslahatan bagi semua manusia dan alam sekitarnya.

\section{B. Pembahasan}

\section{Keberagamaan Inklusif Anak Usia Dini}

Pemahaman lain tentang anak adalah anak merupakan manusia yang memiliki potesi yang masih harus dikembangkan. Anak memiliki karakterisik tertentu yang khas dan tidak sama dengan orang dewasa serta akan berkembang menjadi manusia dewasa seutuhnya. Dalam hal ini anak merupakan seorang manusia atau individu yang memiliki pola perkembangan dan kebutuhan tertentu yang berbeda dengan orang dewasa. Anak memiliki berbagai macam potensi yang harus dikembangkan meskipun pada umumnya anak memiliki pola perkembangan yang sama, tetapi ritme perkembangannya akan berbeda satu sama lainnya karena pada dasarnya anak bersifat individual (Hartati, 2005: 7). Oleh karena itu lingkungan mempunyai peran yang sangat penting untuk 
membangun sikap toleransi keberagamaan inklusif. Selanjutnya jika lingkungan tidak mampu mengembangkan sifat individual anak besar kemungkinan kelak anak bersifat eksklusif.

Definisi yang umum digunakan adalah yang dikemukakan oleh NAEYC (National Assosiation Education For Young Children) bahwa anak usia dini adalah kelompok individu yang berada pada rentang usia antara 0-8 tahun. Sedangkan menurut UU No 20 tahun 2003 tentang sistem pendidikan Nasional BAB 1 Pasal 1 Butir 14 menyatakan bahwa PAUD merupakan suatu upaya pembinaan yang ditujukan pada anak sejak lahir - 6 tahun yang dilakukan rangsangan pendidikan untuk membantu pertumbuhan dan perkembangan pendidikan jasmani dan rohani agar anak memiliki kesiapan belajar dalam memasuki pendidikan lebih lanjut. Oleh karena itu yang dimaksud AUD adalah anak pada rentang usia 0-8tahun, sedangkan PAUD adalah anak pada rentang usia 0-6 tahun.

Hal ini mengisyaratkan bahwa anak merupakan individu yang unik dimana memiliki pola pertumbuhan dan perkembangan dalam aspek kognitif, bahasa, sosial emosional, bahasa, psikomotor dan nilai moral agama sesuai dengan tahapan yang sedang dilalui anak. Karakteristik AUD yang khas menurut Richard D. Kellough (1996), yaitu: Anak itu bersifat egosentris, memiliki rasa ingin tahu yang besar, anak adalah makhluk sosial, anak bersifat unik, anak umumnya kaya dengan fantasi, anak memiliki daya konsentrasi yang pendek, anak merupakan masa belajar yang paling potensial. Dengan memahami karakteristik anak, sekiranya akan memudahkan orangtua untuk memberikan pembelajaran yang tepat dalam membangun sikap toleransi pada anak.

Dewasa ini, toleransi berkaitan dengan kemampuan mengolah emosi dan karakter. Sikap toleran ini termasuk dalam kecerdasan emosional yang lebih cenderung kepada softskiil yang berkontribusi $80 \%$ pada keberhasilan seseorang di dunia kerja sementara kecerdasan intelektual (IQ) hanya berkontribusi 20\%. Pendidikan hendaknya mampu mengantarkan anak didik kearah yang melihat 
masa depan sebagai sebuah harapan baru. Walaupun kenyataannya Human Development Indek (HDI) masih berada dibawah Negaranegara lain, hal ini menunjukkan bahwa masih rendahnya SDM di Indonesia, yang secara langsung hal ini menunjukkan tentang kualitas pendidikan di Indonesia. Hal ini tentunya tidak dapat menghasilkan manusia - manusia yang berkualitas, sehingga penting dijadikan refleksi bagi dunia pendidikan untuk mempersiapkan generasi yang akan datang sejak dini (Marhumah, 2013: 73-74). Refleksi ini dapat dilakukan salah satunya melalui pendidikan anak dalam keluarga. Pendidikan anak dalam keluarga mempunyai peran yang lebih urgen dan lebih banyak mempengaruhi perkembangan anak. Karena waktu yang dihabiskan anak lebih banyak dengan keluarga daripada pendidikan formal. Bahkan secara langsung sifat dan sikap sosial orangtua akan terwariskan kepada anak-anaknya baik sadar ataupun tidak, hal demikian karena masa anak-anak masih berapada pada masa golden age. contohnya, sikap inklusif dan ekslusif yang dimiliki orang tua secara langsung akan tertanam dalam diri anak. Selanjutnya lingkungan dengan pemahaman keberagamaan inkusif akan membantu membangun sikap toleran pada anak.

Membangun pemahaman keagamaan yang humanis dan inklusif atau pemahaman keberagamaan inklusif memiki peran signifikan dalam konteks kehidupan sekarang. Dalam formulasinya, yaitu masyarakat Indonesia yang pluralis (Aim dan Sauqi, 2011: 152). Pluralisme bukanlah memandang secara sama terhadap semua keragaman. Pluralisme tidak juga sekedar pemahaman bahwa masyarakat yang majemuk, beraneka ragam yang terdiri dari suku dan agama lebih dari itu semua, pluralisme difahami sebagai patokan sejati kebhinekaan dalam ikatan keadaban (Aim dan Sauqi, 2011: 253). Dalam hal ini dapat difahami bahwa dalam keberagamaan inklusif tanpa harus mengorbankan aspek norma atau kurang etis dengan kata lain attitude. Pada implementasi keberagamaan inklusif harus dilandasi oleh sikap toleransi. Toleransi merupakan sikap untuk menghormati, sikap dasar, keyakinan dan 
perilaku yang dimiliki oleh orang lain (Aim dan Sauqi, 2011: 253) atau dalam bahasa jawa disebut dengan istilah teposaliro. Sikap toleransi dapat dibangun melalui pembentukan identitas anak, sehingga anak akan lebih memahami siapa dirinya dan percaya diri dengan apa yang dianutnya. Oleh karena itu, dapat disimpulkan bahwa keberagamaan inklusif pada AUD adalah kesadaran dalam keberagaman keberagamaan yang dilandasi oleh sikap toleransi, yang dibangun melalui pembentukan identitas anak. Keberagamaan inklusif mempunyai perspektif bahwa setiap anak itu berbeda yang perlu dipenuhi kebutuhannya. Dengan memperhatikan implementasi kurikulum sesuai dengan karakteristik anak. Atau menurut Jemaat Ahmadiyah sesuai dengan silabus. Contohnya seperti silabus ta'lim dan silabus waqf E Nou.

\section{Pendidikan Anak dalam Keluarga Ahmadiyah Manislor Kuningan Jawa Barat}

Pendidikan anak dalam keluarga, sangat menjadi konsen para orangtua keluarga Jemaat Ahmadiyah, khususnya pada PAUD (hasil wawancara dengan Ida S., 2015). Hal demikian sama dengan isi dari salah satu silabus bagi orangtua Waqf E Nou (2010) bahwa orangtua membiasakan diri untuk membiasakan mengawasi/memantau kegiatan bermain anak-anak mereka dari pada membiarkannya bermain sendiri. Hal demikian karena keluarga mempunyai peranan lebih penting dalam membangun tumbuh kembang anak dalam aspek apapun. Selain itu orangtua mempunyai kewajiban untuk mendidik anak-anaknya, sebagaimana firman Allah SWT sebagai berikut :

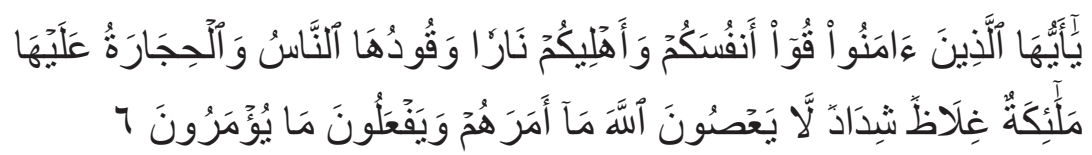

Artinya : Hai orang-orang yang beriman, peliharalah dirimu dan keluargamu dari api neraka yang bahan bakarnya adalab manusia dan batu; penjaganya malaikat-malaikat yang kasar, keras, dan tidak mendurhakai Allah terhadap apa yang diperintabkan-Nya kepada mereka dan selalu 
mengerjakan apa yang diperintahkan. (QS. At Tahrim: 6)

Perintah memelihara diri dalam tersebut adalah pemeliharaan iman dan peningkatan amal saleh dan akhlak mulia karena dengan hal ini seseorang akan terhindar dari ancaman siksa neraka. Pembinaan dan pemeliharaan akan tercapai melalui pendidikan. Oleh karena itu, betapa sangat pentingnya pendidikan anak dalam keluarga.

\section{a. Pembiasaan}

Interaksi keberagamaan inlusif anak-anak Jemaat Ahmadiyah Manislor Kuningan Jawa Barat yang notabene berada pada lingkungan Jemaat Ahmadiyah dalam satu kompleks antara lain dipengaruhi oleh beberapa faktor, yaitu (1) pengetahuan tentang keberagaman, (2) pekerjaan, (3), pola hidup orangtua (hasil wawancara dengan Ida S., 2015) (4) tetangga terdekat dan (5) pendidikan (hasil wawancara dengan Dewi dkk., 2015). Pengetahuan tentang toleransi dikenalkan kepada anak, bahwa kita harus berteman dengan siapa saja tanpa memandang latar belakang. Bagi orangtua yang pekerjaannya berpindah-pindah, secara lansung anak-anak akan belajar tentang keberagaman, bahkan pada lintas agama sekipun. Misalnya, saling berkunjung pada hari besar agama yang dianutnya, walaupun tidak sesuai dengan tanggal perayaan. Selain itu tradisi berkunjungpun dengan membawakan buah tangan yang sekiranya diperhatikan halal dan haramnya.

Pola hidup orangtua yang sudah semakin sering beinteraksi secara langsung dengan masyarakat lintas agama/keyakinan baik dalam kegiatan sosial kemasyarakatan, akan mampu membelajarkan kepada anak secara langsung untuk dapat bersosialisasi dengan keberagamaan inklusif karena anak dapat secara langsung melihat kegiatan sosial kemasyarakatan walaupun belum difahami oleh anak pada tahap keberagamaan inklusif.

Tetangga terdekat, juga akan menentukan seberapa besar toleransi keberagamaan di kenalkan, bagi keluarga Jemaat Amadiyah 
yang mempunyai tetangga yang berbeda keyakinan/agama maka anak akan lebih dapat hidup inklusif lebih baik daripada tetangga yang homogen. Berbeda halnya jika orangtua yang bersikap eksklusif pada tetangganya yang berbeda keyakinan, maka secara langsung akan membentuk anak-anak yang ekslusif. Hal demikian terlihat dari adanya orangtua yang tidak menghadiri kegiatan pengajian tetangga yang non ahmadi walaupun sudah diundang dalam kegiatan tersebut dan walaupun kenyataannya mereka masih saling bersosial dengan baik (hasil wawancara dengan Hj A., 2015).

Tingkat pendidikan orangtua, akan sangat mempengaruhi perkembagan keberagamaan inklusdif AUD. Hal demikian terlihat pada orangtua dengan pendidikan rendah, akan secara langsung mengajarkan kepada anak-anak tentang toleransi melalui bahasa yang sangat verbal. Contohnya, "masjid kita disini, jadi sholatnya disini saja," tanpa memberikan penjelasan yang sesuai dengan karakteristik bahasa anak sehingga besar kemungkinan anak akan tumbuh menjadi anak-anak yang kurang kritis. Berbeda dengan orangtua yang berpendidikan tinggi, akan lebih humanis dalam memberikan pemahaman. Contohnya, keberagamaan inklusif akan diajakan kepada anak melalui hal yang paling luas bahwa kita beragam, oleh karena itu harus saling menghargai dan menghormati.

Faktor-faktor ini akan membetuk keberagamaan inklusif atau eksklusif pada anak tergantung pada pembiasaan interaksi yang dilakukan oleh lingkungan keluarga. Hal demikian karena karakteristik anak adalah egosentris dan memiliki rasa ingintahu yang besar (Hartati, 2005: 8-9). Pada umumnya anak bersifat egosentris. Anak cenderung melihat dan memahami sesuatu dari sudut pandang dan kepentingannya sendiri. Karakteristik seperti ini terkait dengan perkembangan kognitifnya yang menurut Piaget terdapat pada masa praoprasional (2-7 tahun), dimana pola fikir anak bersifat egosentis dan simbolik. Dalam keberagamaan inklusif disini anak-anak berfikir secara simbolik tentang inklusifitas dan eksklusifitas pada bahasa verbal ataupun body language lingkungan keluarga. 


\section{b. Love For All Hatred For None (AUD) dan Difabilitas}

Jemaat Ahmadiyah mempunyai konsep toleransi yang sangat luar biasa yaitu Love For All Hatred For None atau welas asih untuk semua tanpa kebencian bagi siapapun. Betapa besar pengaruh pemahaman akan pentingnya persahabatan, persaudaraan dan perdamaian untuk membangun dunia berlandaskan konsep “Rahmatal Lil'alamin”. Kekuatan sabar sebagai amunisi yang tak pernah habis untuk mmerangi "kekerasan nafsu"(Mutaqi, 2015).

\section{c. Dialog AUD dan Difabilitas}

Secara umum, keluarga Jemaat Ahmadiyah selalu berdialog dengan anak-anak mereka dalam berbagai hal. Termasuk pada program terbiyat keluarga, contohnya seperti (1) mematikan TV setelah magrib dan diisi dengan kegiatan membaca Al-quran, (2) pembiasaan sholat jamaah di Masjid, (3) membaca buku minimal 15 menit perhari, (4) melaksanakan silabus sesuai usia untuk anak-anak wakaf E Noe, (5) membiasakan menulis surat untuk Huzur baik meminta di doakan, atau sekedar berkeluh kesah (hasil wawancara dengan Aah, 2015). Dalam dialog keberagamaan inklusif anak, masih pada tahap bermain bersama, tetapi lebih pada satu komunitas.

\section{d. Membangun Jiwa Sosial Kemasyarakatan AUD dan Difabilitas}

Membentuk jiwa kemasyarakatan adalah interaksi anak dengan masyarakat disekitarnya, baik dengan orang dewasa dan teman sebaya agar mampu bersikap aktif dan positif. Sehingga anak dapat memberi dan menerima dengan sopan santun, berkumpul dan berteman dengan baik. Membentuk jiwa sosial ini dapat dilakukan dengan cara mengajak anak dalam majelis orang dewasa, mengutus anak untuk melaksanakan keperluan, membiasakan anak mengucapkan salam, menjenguk orang sakit, mencarikan teman yang baik, membiasakan anak berdagang, mengajak anak menghadiri perayaan yang disyariatkan, mengajak anak menginap di tempat kerabatnya yang saleh (Hafidz an Nabawi, 2010: 380-391). 
Pernyataan ini dapat dijadikan salah satu alat untuk melihat lebih jauh, bagaimana Jemaat Ahmadiyah mempunyai jiwa sosial kemasyarakatan baik pada lingkungannya sendiri ataupun pada lintas keyainan/agama. Jiwa sosial kemasyarakatan yang dilakukan oleh Jemaat Ahmadiyah antara lain adalah membagikan sembako mendekati hari Raya idul fitri, walaupun dalam praktiknya mengalami banyak kendala seperti ditolak ataupun dilarang oleh masyarakat sekitarnya. Aksi donor darah dan donor mata, bakti sosial pada lintas agama dll (hasil wawancara dengan Ida, Aah dan Dewi, 2015). Selain itu, anak-anak amadi selalu diikut sertakan pada kegiatan majlis orang dewasa, sholat jamaah di masjid, pembayaran candah dll. Membayar candah/iuran dengan tangan mereka sendiri sejak dini, akan membangun anak-anak menjadi generasi yang tangguh, dermawan dan memiliki ruh wakaf (Anam, t.th. : 14). Orangtuapun telah menerapkan petunjuk ta'lim dan tarbiyat, bahwa orangtua perlu memberikan kepada anak-anak uang ataupun barang dalam jemlah tertentu, lalu tekankan pada mereka agar mau memberikan sebagian dari uang/barang kepada orang lain. Kaena hal ini akan menumbuhkan sifat sedekah ata menolong kepada saudara ataupun orang miskin. Demikian juga ajarkan sikap saling tolong menolong, dan bekerjasama (Waqf E. Nou, 2010: 5).

\section{Implementasi Keberagamaan Inklusif AUD pada Keluarga Ahmadiyah Manislor Kuningan Jawa Barat}

Keberagamaan inklusif pada AUD adalah kesadaran dalam keberagaman keberagamaan yang dilandasi oleh sikap toleransi, yang dibangun melalui pembentukan identitas anak. Keberagamaan inklusif mempunyai perspektif bahwa setiap anak itu berbeda yang perlu dipenuhi kebutuhannya. Dengan memperhatikan implementasi kurikulum sesuai dengan karakteristik anak.

\section{a. Kesadaran Toleransi AUD dan Difablitas}

Kemanusiaan yang adil dan beradab hanya bisa hidup dalam 
kebaikan toleransi untuk keadilan hidup setiap orang. Toleransi berarti memberikan hak kepada setiap manusia untuk menjadi diri sendiri, mengormati kebebasan jati diri untuk hidup dalam perbedaan, memberikan rasa adil, aman dan nyaman kepada setiap orang dalam keragaman dan perbedaan, menjaga hati nurani yang bersih saat berinteraksi dengan orang lain yang berbeda dengan diri kita dan memberlakukan setiap orang dengan hormat (www. djajendra-motivator). Selanjutnya kesadaran toleransi dapat dimulai dengan cara seringnya berinteraksi secara langsung pada lingkungan yang beragam. Sedangkan yang dimaksud toleransi pada AUD adalah ketika anak mampu berinteraksi secara langsung dengan anak-anak lain yang berbeda agama/keyakinan dan lebih luas lagi pada keberagaman. Contohnya, ketika anak telah mampu bermain bersama dengan teman-temannya yang berbeda keyakinan/agama. Dengan seringan berinteraksi bersama, secara langsung kesadaran toleransi akan terbentuk pada diri anak.

Kesadaran toleransi anak-anak Jemaat Ahmadiyah Manislor Kuningan Jawa Barat, terlihat pada adanya kesempatan bermain antara anak ahmadi dan non ahmadi yang rumahnya berdekatan/ bertetangga dan adanya kesempatan bersekolah di sekolah umum, yang notabene terdapat anak-anak ahmadi dan non ahmadi sehingga terjalin hubungan pertemanan yang baik. Berbicara pada ranah pendidikan, hanya pada tingkat prasekolah dan sekolah dasar yang umum, untuk tingkat atas, anak-anak Jemaat Ahmadiyah bersekolah pada Lembaga pendidikan milik Jemaat sendiri. Tidak dipungkiri bahwa pada tingkat Prasekolah jemaat mempunyai sekolah sendiri yang kebanyakan adalah anak-anak ahmadi walaupun terdapat 1-2 anak yang non ahmadi (hasil wawancara dengan Ida, Aah, Dewi, dkk, 2015), hal ini menjadi kurang efektif untuk membangun kesadaran toleransi, kecuali ada tawaran lain misalnya dengan mengusung pendidikan multikultural.

Kesadaran toleransi AUD Ahmadiyah Manislor Kuningan Jawa Barat yang nota bene berada pada lingkungan/komunitas 
Ahmadiyah menjadikan sangat mungkin anak-anak dapat tumbuh dan berkembang dengan kesadaran toleransi yang baik, bahkan dapat menciptakan lingkungan yang iklusif karena Jemaat Ahmadiyah mempunyai konsep-konsep untuk membangun kesadaran toleransi, apalagi konsep ini langsung diterapkan dilingkungan keluarga. Tetapi, kenyataannya inteaksi AUD Jemaat Ahmadiyah lebih pada komunitasnya sendiri, misalnya lingkungan masjid dan Sekolah. Hal ini diperkuat oleh adanya anak ahmadi yang tidak mempunyai teman non ahmadi atau hanya mempunyai satu teman non ahmadi dan pernah bermain bersama sekali (hasil wawancara dengan B, dkk., 2015) padahal lingkungannya masih pada satu kampung. Hal demikian secara tidak sadar lama kelamaa akan membentuk lingkungan yang eksklusif, tetapi hal ini masih dapat diperbaiiki dengan membangun lingkungan yang inklusif pada anak.

\section{b. Membangun Identitas Anak AUD dan Anak Difabilitas}

Keberagaman inklusif AUD yang yang dibangun dengan sikap toleransi, dengan cara membangu kesadaran toleransi melalui interaksi tidak akan mampu membangun sikap toleransi secara utuh tanpa adanya pembelajaran identitas pada anak. Pembelajaran identitas pada AUD akan membangun anak-anak yang mempunyai sikap toleran yang baik, dengan sikap percaya diri yang tinggi pada dirinya sendiri serta agama/keyakinan yang dianutnya. Pembelajaran identis pada AUD, dapat dilakukan secara sedehana dan dapat dilaksanakan pada lingkungan pendidikan formal maupun informal. Contohnya adalah, "my name is ..., I am Moeslim Iam abmadiyah, I am school at ect. Hal demikian juga akan membuat orangtua bangga saat mendegar anaknya dengan bangga mengatakan bahwa dia adalah anak ahmadi. Sekiranya hal ini sangat perlu untuk diterapkan dalam rangka membangun keberagamaan inklusif pada AUD. Karena, implementasi seperti ini belum dilakukan oleh pendidikan informal maupun formal di Jemaat Ahmadiyah Manislor Kuningan Jawa Barat (hasil wawancara dengan Ida, Aah, Dewi, dkk., 2015). 


\section{c. Memenuhi Kebutuhan Anak}

Memenuhi kebutuhan anak, dalam rangka membangun keberagamaan inklusif AUD, merupakan hal yang wajib, karena memenuhi kebutuhan setiap anak yang berbeda merupakan salah satu upaya hidup yang humanis untuk membangun kesadaran toleransi dalam keberagamaan. Kebutuhan jasmani dan rohani yang terpehuni sesuai kebutuhan dan perkembangan anak,akan lebih ideal dalam membangun keberagamaan inklusif AUD. Keluarga Jemaat Ahmadiyah dalam hal memenuhi kebutuhan anak di lakukan sebaik mungkin, dengan memberikan pendidikan yang terbaik, meperhatikan kesehatan, kasih sayang baik dari hal-hal yang sederhana maupun teknologi. Apalagi bagi anak-anak wakaf e noe, akan mendapatkan program pengembangan diri yang lebih banyak dan menarik, seperti lomba keagamaan, fasilitas teknologi (Alquran digital) dll (hasil wawancara dengan Ida, Aah, Dewi, dkk., 2015). Program kebutuhan jasmani dan rohani, terprogram dengan rapi melalui buku panduan / silabus waqf e nou dan program-proram pendidikan anak, baik pola asuh, penanaman nila-nilai kehidupan melalui program parenting yang diimplementasikan pada lingkungan keluarga.

\section{Simpulan}

Keberagamaan inklusif pada AUD adalah kesadaran dalam keberagaman keberagamaan yang dilandasi oleh sikap toleransi, yang dibangun melalui pembentukan identitas anak. Keberagamaan inklusif mempunyai perspektif bahwa setiap anak itu berbeda yang perlu dipenuhi kebutuhannya. Dengan memperhatikan implementasi kurikulum sesuai dengan karakteristik anak. Atau menurut Jemaat Ahmadiyah sesuai dengan silabus. Contohnya seperti silabus ta'lim dan silabus waqf e nou.

Pendidikan anak dalam keluarga, sangat menjadi konsen para orangtua keluarga Jemaat Ahmadiyah, khususnya pada 
AUD. Pendidikan ini dapat dilakukan melalui konsep ataupun implementasi sebagai berikut, yaitu pembiasaan, love for all hartred for none, dialog dan membangun jiwa sosial kemasyarakatan anak. Implementasi keberagamaan inklusif AUD: toleransi Keberagamaan AUD pada Keluarga Ahmadiyah Manislor Kuningan Jawa Barat, dibangun melalui kesadaran toleransi, pemenuhuhan kebutuhan setiap anak dan perlu membangun identitas anak. 


\section{DAFTAR PUSTAKA}

Aah. (2015). Hasil Wawancara "Keberagamaan Inklusif AUD", Manislor, Kuningan Jabar, Sabtu, 24 Oktober 2015, jam 14.00-15.30 WIB.

Aim, N. \& Sauqi, A. (2011). Pendidikan Mltikultural Konsep dan Aplikasi, Cet ke III, Yogyakarta: Ar Ruzz Media.

Anam, M. K. (t.th). Membangun Karakter Generasi Muda yang Islami, Mubalig Wajo, Sidrap dan Bone, Sulawesi Selatan.

An-Nadawi, M. N. A. H. (2010). Prophetic Parenting: Cara Nabi Mendidik Anak. Yogyakarta : Pro U Media.

B, dkk. (2015). Hasil wawancara dan observasi Bermain bersama teman, 23-24 Otober 2015. Manislor, Kuningan Jawa Barat.

Dewi, dkk. (2015). Hasil wawancara dengan tema Keberagamaan Inklusif AUD. Sabtu, 24 Oktober 2015, jam 14.00-17.00 WIB.

Hartati, S. (2005). Perkembangan Belajar pada Anak Usia Dini. Jakarta: Departemen Pendidikan Nasional Direktorat Jenderal Pendidikan Tinggi Direktorat Pembinaan Pendidikan Tenaga Kependidikan dan Ketenagaan Tinggi Jakarta.

Hj. A. (2015). Hasil Wawancara dengan tema Toleransi, Sabtu, 24 Oktober 2015, jam 08.00-11.00 WIB.

http.//www.djajendra-motivator, Toleransi adalah energy untuk kehidupan yang adil dan beradap, diunduh pada tanggal 5 November 2015.

Ida S. (2015). Hasil wawancara Keberagamaan Inklusif AUD, Jumat, 23 Oktober 2015, jam 07.00-10.00 WIB

Ida, Aah, Dewi dkk. (2015). Hasil Wawancara Keberagamaan Inklusif. Manislor, Kuningan Jabar, Sabtu, 24 Oktober 2015, jam 14.00-17.00 WIB.

Marhumah. (2013). Urgensi Pendidikan Multikutural bagi Anak Usia Dini, “Jurnal”Antologi Pendidikan Anak Usia Dini dalam 
Pendidikan Dasar Islam, Yogyakarta: Pasca sarjana UIN Sunan Kalijaga Yogyakarta.

Mutaq, A. S. (2015). Implementasi Konsep Rahmatan Lil'alamin dalam Kehidupan Keseharian, dipresentasikan pada Pembekalan Field Research, Selasa 20 Oktober 2015, Yogyakarta : ISAIS.

Perez, Z. (2003). How the Idea of Religious Toleration Came to the West, T. Kt: Princeton University Press.

Tn. (2010) Syllabus Waqf E Nou Petunjuk Ta'lim dan tarbiya Bagi Para Orangtua Waqf e Nou, Cet ke II, Bogor : Sekretais Waqf E Nou Pengurus Besar JAI. 
Halaman ini bukan sengaja untuk dikosongkan 